\title{
An Assessment of Local Economic Empowerment Using Halal Tourism Approach: A Case from Sembalun District East Lombok, Indonesia
}

\author{
${ }^{1}$ Ima Rahmawati Sushanti, ${ }^{2}$ Mustamin H. Idris, ${ }^{3}$ Baiq Harly Widayanti, ${ }^{4}$ Fariz \\ Primadi Hirsan, ${ }^{5}$ Lukman Abdullah, 6 Intan Savia Fitri \\ 1,2,3,4,5,6Universitas Muhammadiyah Mataram, Mataram, Indonesia \\ 1imarahmawati@gmail.com, ${ }^{2}$ mustamin@gmail.com, ${ }^{3}$ baiqharly@gmail.com, ${ }^{4}$ farizprimadi@gmail.com, \\ 5lukmanabdullah@gmail.com, 6intansavia@gmail.com
}

\begin{tabular}{|c|c|}
\hline Article Info & bstract \\
\hline $\begin{array}{l}\text { Article History } \\
\text { Received: July 12, } 2018 \\
\text { Accepted: September 30, } \\
2018\end{array}$ & \multirow{2}{*}{$\begin{array}{l}\text { This study aimed to assess the local economic empowerment based on halal } \\
\text { principles in Sembalun, a village within the circumference of Rinjani, the } \\
\text { newly-designated world geopark by UNESCO. The descriptive qualitative } \\
\text { method was chosen to analyze the data. The Participatory Rural Appraisal } \\
\text { was used as an instrument to identify the expectations of the economy of } \\
\text { local community. The study showed that local economic empowerment could } \\
\text { be developed in several ways as follows: 1) Halal food initiative through } \\
\text { increasing community participation and skills, involving institutions, } \\
\text { providing intensive assistance, and increasing the role of community and } \\
\text { institution in creating cooperation; 2) Worship facility improvement through } \\
\text { increasing quality and maintenance of available worship facilities; 3) } \\
\text { Services during Ramadan by improving the community and institutional } \\
\text { capacity as well as delivering information to tourism operators and visitors; } \\
\text { 4) Supporting facilities upgrading through increasing the numbers of water- } \\
\text { friendly toilets both in quantity and quality; 5) Halal activities enrichment by } \\
\text { eliminating non-halal activities and promote halal activities only; } 6 \text { ) Privacy } \\
\text { leisure facilities and services provision through increasing institutional and } \\
\text { community capacity in providing privacy leisure facilities and services as } \\
\text { well as developing cooperation with stakeholders. }\end{array}$} \\
\hline \begin{tabular}{lr}
\multicolumn{2}{l}{ Keywords } \\
Halal Tourism; & \\
Empoopark; \\
Economy
\end{tabular} & \\
\hline & \\
\hline
\end{tabular}

\section{INTRODUCTION}

Tourism in Indonesia is one sector that has great potential and deserves to be developed and managed optimally. The influence of the development of the tourism sector has recently become an important concern as the largest foreign exchange contributing sector after the oil and gas sector. The tourism sector is one of the mainstay sectors for national development because it can increase revenues through the country's foreign exchange and also become a leading sector that plays an important role in economic development. As mentioned in Sunaryo (2013) [5] that in addition to being a source of foreign exchange earnings, tourism also serves as an instrument of equity development and community renewal (adoption of technology and modernization values). In addition, Lakshmi and Shaji (2016) [2] say that tourism is a major economic activity that can bring significant changes to the lives of people in the tourism destinations both in terms of economic growth, infrastructure development and improving standards of living

Halal tourist destination becomes a new brand for West Nusa Tenggara province developed through the existing tourism potential, especially in District Sembalun, East Lombok. Rinjani circle area is one of the world destinations that have been established 
as a UNESCO World Geopark area through Geoculinary, Geohomestay, Geosouvenir, and Geotour products [6]. One of the areas that have a diversity of tourism potential by presenting a variety of natural beauty and culture is very interesting to visit is Sembalun District. Sembalun district is one of the districts belonging to the Rinjani ring area which has many natural potentials and potential resources that can be developed through local economic empowerment. Halal tourism is a tourism activity with tourism destination and tourism industry that prepare product facilities, service, and tourism management that fulfill syari'at (Piece of the Province NTB No. 2 the Year 2016) [3]. Development of halal tourism area Rinjani circle in District Sembalun, East Lombok is potential to serve as a new object that can increase the potential of the region. The existence of local potentials in Sembalun district, East Lombok is not currently supported by the involvement and active role of the community and institutions in supporting local potentials. So this research aims to study local economic empowerment based on halal tourism area of Rinjani circle in Sembalun district, East Lombok, Indonesia.

\section{METHOD}

The method of this research is qualitative descriptive using primary data in the form of observation and interview and using secondary data in the form of a journal, book, and related documents obtained from the institution and using the Participatory Rural Appraisal analysis is used as an instrument to identify the expectations of society towards the empowerment of the local economy.

\section{RESULT}

\section{Distribution of Local Potential in Sembalun District}

Based on UNESCO Recommendation, there are some local potential especially in Sembalun Subdistrict, East Lombok regency can be divided into several geo product potentials such as Geokuliner, Geohomestay, Geosouvenir, and Geotour products. The spread of local potentials can be described as follows.

1. Geo souvenir

Geo souvenir is a development of souvenirs made from local with forms and themes related to geopark Rinjani. The potential of geo culinary in Sembalun District, East Lombok Regency based on UNESCO recommendation is in Sembalun Village with a product of T-shirt with wicker packaging, keychain.

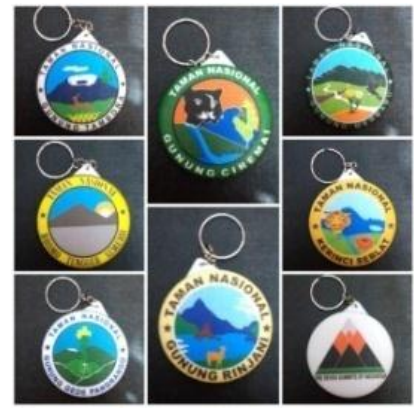

Figure 1: Geosouvenir in Sembalun District

2. Geoculinary

Geoculinary is a local culinary potential given naming in relation to geological terms and geopark Rinjani. The potential of geoculinary in Sembalun District, East Lombok based on recommendation of UNESCO is in Sembalun Lawang 
Village with the product of organic bread with raw material of potato, strawberry and carrots and in Sembalun Bumbung Village with processed products of fresh food (tomato, potato, onions) to be packed and marketed to hotels and restaurants.

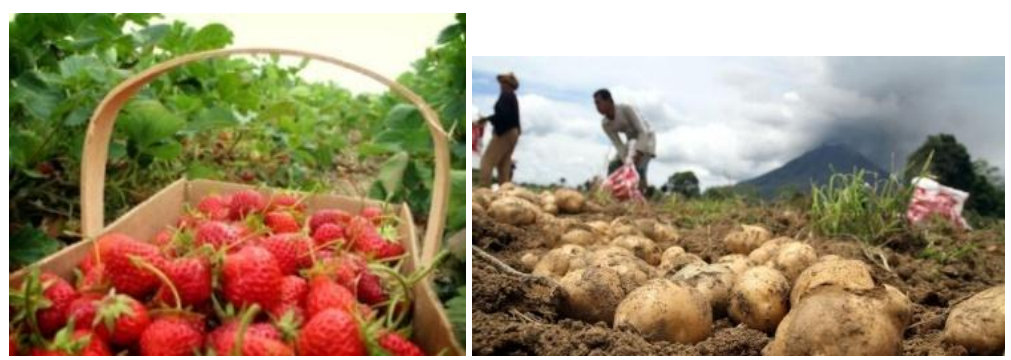

Figure 2: Geoculinary in Sembalun District

3. Geotour

Geotour is a tour package that combines the destination with the richness of geology, biological wealth, cultural richness coupled with the involvement of schools and small industries of society as part of tourist destinations to be visited by tourists. Geotourism potential in Sembalun District, East Lombok based on UNESCO recommendation is in the valley of Sembalun (Pergasingan Hill and Selong Hill), Sembalun Valley (Sembalun Village), Sembalun Beleq Village, Mangkusakti Waterfall.

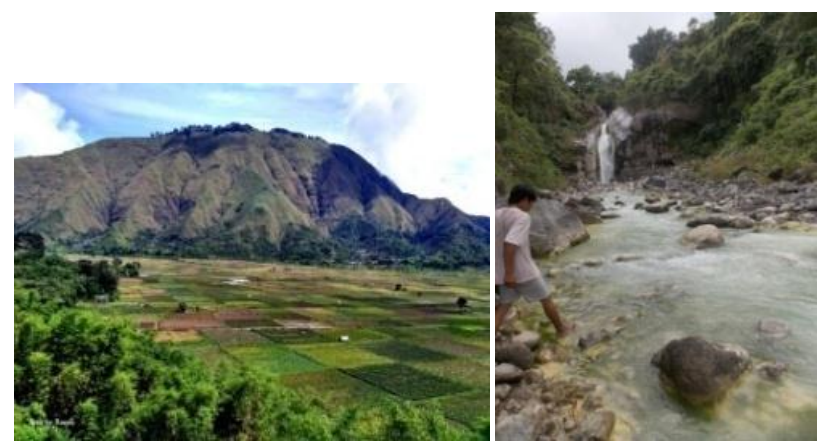

Figure 3: Geotour in Sembalun District

4. Geohomestay

Geohomestay is the resident's homes are raided with the theme of geopark of information board as the interior is equipped with brochures related to geopark Rinjani Lombok and functioned as lodging that can be rented by tourists at affordable prices. The geohomestay potential in Sembalun District, East Lombok based on UNESCO recommendation, there are 3 Homestay units with development needs in the form of toilet seat and service and processing. 


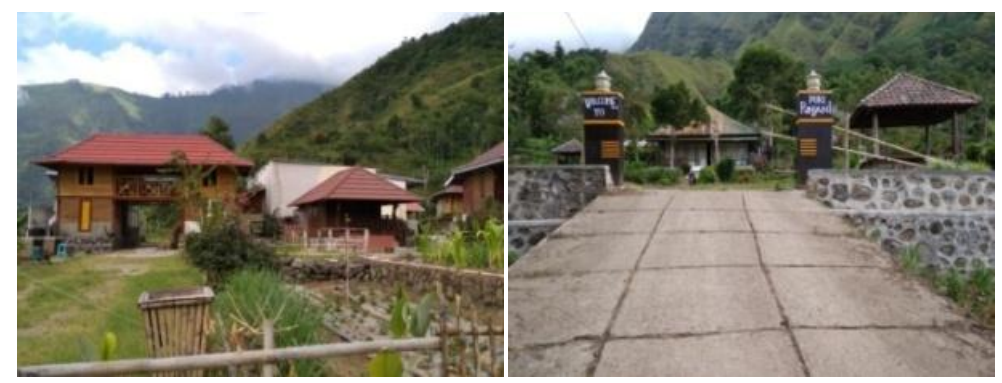

Figure 4: Geohomestay in Sembalun district

\section{Characteristics of Sembalun District}

1. Population

Sembalun District \pm 217.08 square kilometers with the population in Sembalun District, East Lombok in 2017 currently amounted to 20,980 people consisting of 10,411 male and 10,569 female with population density 1,50 $\mathrm{Ha}$ /soul.

Residents who reside in the Sembalun area are often called 'Orang Sembalun', they claim to be from Sasak ethnic and in local history are believed to be the oldest in Sembalun who most dominantly resides in this area and generally in Lombok Island. In addition, there are newcomer residents from surrounding villages, from Bali and Java, and dominant Muslims.

2. Livelihood and Income Society

The people in Sembalun district, East Lombok are mostly livelihoods as farmers. This is evidenced by the large number of community farms that are near their homes with excellent potentials such as potatoes, chili, tomatoes, strawberries, onions, and garlic. However, not only as a farmer, the people in Sembalun district also work in the livestock sector. This can be seen from the people who keep cows around the house with a considerable amount.

The people in Sembalun are mostly a livelihood as farmers. This is evidenced by the large number of community farms that are near their homes with excellent potentials such as potatoes, chili, tomatoes, strawberries, onions, and garlic. However, not only as a farmer, the people in Kecamatan Sembalun also work in the livestock sector. This can be seen from the people who keep cows around the house with a considerable amount.

Economic activity in Sembalun district in the last two years having an increase in, and has implications for the increase in people's income. Previously the economic activities of the Community were only supported by the agricultural sector in its development, the economy of commerce and livestock also began to grow rapidly. So in addition to the agricultural sector, trade and animal farm sector contribute a large enough for the absorption of manpower. Sembalun district income sources come from several sectors, namely agriculture, plantations, livestock, services, home industry, and trade.

3. Institutional

Community Institution is an institution formed by the community itself as needed and is a partner of the government in order to increase community 
participation in the implementation of development. The establishment of social institutions in Sembalun District, both types and numbers are determined by the situation and conditions and customs prevailing in the community.

The existence of these social institutions is a strategic step in the effort to uphold democratic life and as a vehicle for the process of learning of democracy whose pillars actually exist in society. The representation of various groups and elements in the community is seen in every member of the community institution, so that the social control over the government, service, and development will be better.

With a variety of considerations and demands of community needs and to support the smooth development of activities in Sembalun District, in 2016 can be inventoried the number of social institutions as many as 15 pieces that include:

1) Women's organizations such as Foonding Welfare Family, and Dasawisma Groups.

2) Youth Organizations such as: Sports Clubs, Youths in each race and Mosque Youth or Mosque Society.

3) Professional Organization such as Farmer Group, GAPOKTAN, Club Motorcycle Taxis.

4) Father's organization such as Group of Langaran, and Group of Death Banjar.

5) Gotong Royong Group such as the Month of Bhakti Mutual Cooperation Committee, Gotong Royong Group built the House, Mutual Cooperation Group Cleaning Grave, Gotong Royong Group Planted.

6) The People's Resilience of the Village

In addition, there are community institutions that specifically deal with and coordinate the processing of agricultural products that exist in Sembalun Subdistrict, collectively carried out by housewives in processing agricultural products into processed products as a typical souvenir that can be enjoyed by the public from Sembalun District as a tourist village. The institutions include:

a. Women's Rinjani Women's Group (Processed Black Garlic)

b. Women's Group of Puri Rinjani

c. Jorong Sejahtera Group (Processed Agricultural Products)

d. Sekar Wangi Women's Group (Processed Tomatoes)

e. Women's Group Forward (Processed Tomatoes)

f. Joint Group (Processed Food)

\section{Result of Participatory Rural Appraisal (PRA)}

Participatory Rural Appraisal is one of the instruments used to find out the people's expectation of local economic potential in the surrounding area. The Participatory Rural Appraisal results that have been done in Sembalun District, East Lombok which can be seen from various aspects are among others: 
1) Regional Potential

- The community in Sembalun district, East Lombok about $85 \%$ of the people already knows the potential of the region in the village especially the tourism potential that received much attention from tourists.

- Local people in Sembalun district have tried to maximally support the potentials of their village by managing and planting in an orderly manner related to potato, strawberry, tomato and other agricultural products so that the agricultural products of the community will also increase.

2) Problems / Constraints

- Of the people present in PRA activities, about $15 \%$ of the community stated that there were no obstacles or problems in managing and developing the potentials in their village.

- However, about $85 \%$ of the public stated that there were problems or obstacles in support of potential in their village, the problems include:

a. Low community knowledge in managing and developing potentials within a region

b. Inadequate facilities and infrastructure in support of these potentials

c. The marketing and price of agricultural products that are perceived to be incompatible with limited marketing reach

3) Institutional

- In Sembalun district, East Lombok there is already institutions that specifically deal with the processing of agricultural products into something that can be enjoyed by tourists who come. For example with the manufacture of culinary crackers, potato chips, processing fruit strawberry and other culinary-culinary which will be marketed in the center by-dies.

- Existing institutions are also very participative and have an active role in supporting the existing potentials in Sembalun District.

- Youth groups in Sembalun village are very participating in the process of managing and developing various potentials, especially in the tourism potential.

4) People's Expectations

- The community in Sembalun district, East Lombok hopes that there will be further guidance and assistance to the surrounding community related to the management and development procedures of potentials in their area.

- People hope that the agricultural output they manage will increase.

- People also hope that the existing tours in the Sembalun District can be one alternative tourist destinations that can be visited by tourists both domestic and foreign tourists.

- The community hopes that there will be active local government support and participation in deciding and establishing potentials in Sembalun district that have great potential that can support the region in its development as a tourist village. 


\section{Local Potential Based Driving Direction Halal}

Based on local potential and the result of PRA conducted in Sembalun district, East Lombok, the local economy empowerment direction based on halal tourism of Rinjani circle area is as follows:

(1) Halal food, through efforts to improve community involvement and skills, institutionalization in the production and marketing of halal food, provide intensive assistance to the community, institutions related to the production, marketing and certification of halal food, increasing the active role of society and institutions to build cooperation and information dissemination halal food to tourists and tourists.

(2) Worship facilities, through efforts to improve the quality and maintenance of adequate means of worship.

(3) Services during Ramadan month, through efforts to improve the capacity of the community and institutions and information dissemination to tourism actors and tourists during Ramadan month.

(4) Small, water-friendly toilets, through an effort to increase the number and quality of adequate restrooms.

(5) No non-halal activities, through efforts to improve the capacity of the community, institutions and information dissemination of tourism actors and tourists not to engage in non-halal activities.

(6) Facilities and recreational services with privacy, through efforts to improve community capacity, institutions in the provision and quality of recreational facilities and services with privacy as well as building cooperation with stakeholders.

\section{CONCLUTION}

Based on these studies, we get some conclusions as follows: (1) Sembalun district is one of the areas that have potential in its development as a tourism destination halal with some local potential such as technology, culinary, tour, and homestay. (2) In its development as a halal tourism destination, local potentials in Sembalun district, East Lombok has been well developed but not yet optimal. (3) Based on the results of the Participatory Rural Appraisal (PRA), community in Sembalun district, East Lombok hopes that the local potentials can provide more selling value and contribute greatly in the development of the region into one of the halal tourist destinations that can provide dish and service to Muslim tourists in particular. (4) Based on some potential and result of PRA that have been done, obtained some direction in local economic empowerment based on halal tourism parameter that is: 1) Halal food, through effort to increase community involvement and skill, institute in production and marketing of halal food, intensive assistance to the community, production-related institutions, marketing and halal food certification, enhancing the active role of communities and institutions to build cooperation and dissemination of halal food information to tourism and tourists, 2) Worship facilities, through improving the quality and maintenance of adequate facilities of worship, 3) Services during Ramadan month, through efforts to improve the capacity of the community and institutions and information dissemination to tourism 
actors and tourists during Ramadan month, 4) Small, water-friendly toilets, through an effort to increase the number and quality of adequate restrooms, 5) No non-halal activities, through efforts to improve the capacity of the community, institutions and information dissemination of tourism actors and tourists not to engage in non-halal activities, 6) Facilities and recreational services with privacy, through efforts to improve community capacity, institutions in the provision and quality of recreational facilities and services with privacy as well as building cooperation with stakeholders.

During the month of Ramadan, through efforts to improve the capacity of communities and institutions and information dissemination of tourism and tourists during Ramadan, water-friendly small rooms through efforts to increase the number and quality of rooms to stay is adequate, there are no non-halal activities, through efforts to improve the capacity of the community, the institutional and socialization of information to tourism actors and tourists not to conduct non-halal activities, recreational facilities, and services with privacy, through efforts to improve the capacity of the community, institutions in the provision and quality recreational facilities and services with privacy as well as building cooperation with stakeholders.

\section{REFERENCE}

[1] Global Muslim Travel Index 2016.

[2] Lakshmi, S.R., Prof. Shaji, T.L. 2016. Transformation of Coastal Settlements Due to Tourism. Procedia Technology: 24 (2016) 1668-1680. Elsevier.

[3] Lembar Daerah Provinsi Nusa Tenggara Barat No. 2 Tahun 2016 tentang Pariwisata Halal

[4] Peraturan Daerah Provinsi Nusa Tenggara Barat No. 7 Tahun 2013 tentang EnCana Inuk Pembangunan Kepariwisataan Daerah Tahun 2013-2028

[5] Sunaryo, Bambang, 2013 Kebijakan Pembangunan Destinasi Pariwisata: Konsep dan aplikasinya di Indonesia, Yogyakarta; Gava Media.

[6] UNESCO, 2014.

[7] Widagdyo, K.G. 2015. Analisis Pasar Pariwisata Halal Indonesia. The Journal of Tauhidinomics: Vol. 1 No. 1 (2015): 73-80. Universitas Sahid Jakarta. Jakarta. 